\title{
The Negative Impact of Obesity on the Occurrence and Prognosis of the 2019 Novel Coronavirus (COVID-19) Disease: A Systematic Review and Meta-Analysis
}

Research

Keywords:

Posted Date: November 4th, 2020

DOl: https://doi.org/10.21203/rs.3.rs-86237/v2

License: (1) This work is licensed under a Creative Commons Attribution 4.0 International License. Read Full License

Version of Record: A version of this preprint was published at Eating and Weight Disorders - Studies on Anorexia, Bulimia and Obesity on July 11th, 2021. See the published version at https://doi.org/10.1007/s40519-021-01269-3. 


\section{Abstract}

The authors have requested that this preprint be withdrawn due to erroneous posting.

\section{Full Text}

The authors have withdrawn this preprint from Research Square. 